\title{
Landscaping Work: Work-related Musculoskeletal Problems and Ergonomic Risk Factors
}

\author{
Mei Ching Lim' \\ Khamisah Awang Lukman $\mathbb{D}^{1,2}$ \\ Nelbon Giloi' \\ Jac Fang Lim' \\ Hazeqa Salleh' \\ Ahmad Syukri Radzran' \\ Mohammad Saffree Jeffree (D)' \\ Syed Sharizman Syed Abdul \\ Rahim (D) \\ 'Department of Public Health Medicine, \\ Faculty of Medicine \& Health Sciences, \\ Universiti Malaysia Sabah, Kota Kinabalu, \\ Sabah, 88400, Malaysia; ${ }^{2}$ Centre for \\ Occupational Safety \& Health, Universiti \\ Malaysia Sabah, Kota Kinabalu, Sabah, \\ Malaysia
}

Correspondence: Khamisah Awang Lukman Department of Public Health Medicine, Faculty of Medicine \& Health Sciences, Universiti Malaysia Sabah, Kota Kinabalu, 88400, Sabah, Malaysia

Email khamisah@ums.edu.my
Background: Work-related musculoskeletal disorders (WRMSDs) are considered one of the foremost reason of disability globally with significant economic impact due to loss of productivity. Landscaping work is considered a high-risk industry in the service sector. Landscape workers are susceptible to WRMSDs as they are exposed to high physical demands at work, and exert significant physical effort to complete daily repetitive tasks during long working hours. The aim of this study was to determine the prevalence of WRMSDs and to identify the ergonomic risk factors among landscape workers in a university setting.

Methods: This was a cross-sectional study conducted among landscape workers at a public university in Kota Kinabalu, Sabah. Interviews were conducted due to low literacy of the participants, using structured questionnaires which consist of personal characteristics, work descriptions, ergonomic risk factors, as well as self-reported WRMSD symptoms using NORDIC questionnaire. Ergonomic risk assessment (ERA) using rapid entire body assessment (REBA) was then conducted.

Results: Fifty-five of 60 landscape workers agreed to participate ( $92 \%$ response rate). The overall prevalence of WRMSDs among landscape workers was $85.5 \%$. The highest prevalence involving the shoulder (65.5\%), followed by neck (23.6\%), wrist/hand $(23.6 \%)$, and lower back (20.0\%) regions based on their self-reported WRMSD symptoms over the past 12 months. Awkward posture was the risk factor identified through ergonomic risk assessment (ERA) conducted by ERA trained personnel. None of the working postures during assessment was noted to be appropriate. Although no significant difference was associated with self-reported WRMSDs, majority of the landscape workers (71\%) were classified as medium ergonomic risk group using REBA, with the remaining $29 \%$ considered to be high ergonomic risk group.

Conclusion: Improvement in awareness campaigns, modification of working tools, and enhanced administrative approaches are among the control and prevention measures recommended to delay or prevent the occurrence of WRMSDs.

Keywords: awkward posture, landscape workers, work-related musculoskeletal disorders, rapid entire body assessment, REBA

\section{Introduction}

According to the recent report of Global Burden of Disease (GBD) 2019, an estimated 1.71 billion people were affected by musculoskeletal illnesses worldwide with the highest prevalence in the lower back region. ${ }^{1}$ According to the Labour Force Survey (LFS), although there seems to be a downward trend of self-reported work-related musculoskeletal disorders (WRMSDs), there were approximately 480,000 WRMSDs cases with prevalence rate of 1420 per 100,000 workers in $2019 / 2020 .^{2}$ 
Work-related musculoskeletal disorders (WRMSDs) comprise cumulative disorders involving the muscles, ligaments, tendons, cartilage, and the nerves. ${ }^{3-6}$ WRMSDs can be attributed directly via surrounding work environment or performance of work tasks. ${ }^{7}$ In addition, WRMSDs can also be caused by further aggravation or deterioration of existing musculoskeletal conditions due to inconducive working environment. ${ }^{7,8}$ Over the years, there is a rapid pace of transformation, modernisation, and industrialisation. Hence, the demand for physical occupational load has evolved over time. Manual dependent workers or labourers are expected to work in long hours of static or awkward postures, continuous repetitive movements, rapid work activities, and forceful exertion, which are risk factors for WRMSDs. ${ }^{2,9,10}$ Hence, WRMSDs were reported to be more predominant in industries which comprise agriculture, forestry and fishing group, construction group as well as healthcare and social work activity group. $^{2}$

WRMSDs evolve over a period of time and reach a threshold where the affected or injured structures can no longer sustain their adaptive and repair capacities. ${ }^{11}$ This will then lead to persistent pain (usually severe), which will further limit the daily functions or work tasks of the affected individual. ${ }^{12,13}$ WRMSDs were responsible for $30 \%$ of all work-related illnesses and an estimated 8.9 million working days lost in 2019/2020. ${ }^{2}$

The International Ergonomics Association (IEA) defines ergonomics or human factors as the scientific field that emphasises the understanding of the relationship between humans and other components of a system, as well as the field that applies information, model, principles, and approaches to designing workstations that enhance human well-being and the overall performance of the system. ${ }^{14}$ Implementation of workplace ergonomics is obligatory in order to improve the quality, productivity, and workers' morale, as well as to create a conducive working culture.

Landscaping work, which shares similar job tasks with agricultural workers and gardeners, includes lifting and carrying, stretching, bending over, twisting, and pulling and pushing heavy loads. ${ }^{15}$ Hence, landscaping work is considered a high-risk industry in the service sector. ${ }^{15} \mathrm{~A}$ high proportion of non-fatal injuries were frequently reported among landscape workers. ${ }^{16}$ The injuries may be due to contact with equipment or objects, fall from elevation, transportation, as well as exposure to harmful substances or environments, and overexertion while working. ${ }^{16,17}$ Furthermore, many WRMSDs studies have also been conducted among agricultural workers which included plantation workers and farmers as well as gardeners. ${ }^{18-23}$ The most prevalent WRMSDs were reported in the lower back region (53.3-86.5\%) followed by the neck (23.9-85.9\%) and shoulder regions (21.6$80.9 \%)^{18-23}$

Therefore, ergonomic risk assessment is deemed necessary among landscape workers who are working in potentially hazardous environments. Furthermore, it is also in accordance with the Occupational, Safety and Health Act (OSHA), which highlighted the responsibility of employers in providing and maintaining the safety, health, and welfare of workers in the working environment. $^{24}$

Most landscaping workers at universities are involved in tasks that require manual activities. This include sweeping, raking, cleaning up dry leaves, watering the plants, clearing the drains, and trimming hedges and trees in the university grounds. Hence, the landscape workers are also exposed to awkward postures, such as squatting, kneeling, and bending, for long periods of time, and to other ergonomic risk factors that may result in work-related musculoskeletal disorders. This study aimed to determine the prevalence of WRMSDs and to identify the ergonomic risk factors among landscape workers in a university setting in order to address the limited evidence in this area. The data collected will be beneficial for improving work procedures and practices for landscape workers, in accordance with the guidelines of the Department of Safety and Health (DOSH).

\section{Materials and Methods \\ Study Design and Study Populations}

This cross-sectional study, which involved landscape workers who had worked for at least 12 months with no previous work-related musculoskeletal injuries, was conducted at the main campus of a public university in Kota Kinabalu, Sabah. Ethical approval for the study was obtained from the Ethical Committee of the Faculty of Medicine and Health Sciences University Malaysia Sabah (UMS; Approval Code: JKEtika $1 / 20$ (3)). Fifty-five of 60 landscape workers agreed to participate and consented to the study, which provided a $92 \%$ response rate.

\section{Research Materials}

Assessment of Exposure

For data collection, questionnaires were disseminated to the landscape workers via their supervisor. Nevertheless, 
since most of the workers were of low level of literacy, direct interviews were conducted by the researcher based on the structured questionnaire and were assisted by translators who spoke the local dialect. The questionnaire comprised four sections; (i) Section A: Sociodemographic questionnaire that included personal information like age, sex, ethnicity, education level, smoking status and household income; (ii) Section B: Past Medical and Surgical History; (iii) Section C: Current work history which emphasized on the particulars of their daily task accomplished by the workers such as categories of job tasks, length of working hours, weighty loads that they need to move or carry, their perception of awkward postures and any repetitive work conducted. Previous work experiences were also included to determine any prior risk of WRMSDs; and (iv) Section D: Standardized Nordic Musculoskeletal Questionnaire (SNMQ), which was originally developed by Kuorinka et $\mathrm{al}^{25}$ was used to assess the self-reported work-related musculoskeletal symptoms. $^{26}$ SNMQ comprised of 2 segments : (i) Segment 1: 40 questions with "No" and "Yes" answers, referring to symptoms such as ache, pain, discomfort or numbness in 9 segments of the body (neck, shoulders, elbows, wrist/hands, upper back, lower back hip/thighs, knees and ankles/feet) during the last 12 months, during the last 7 days and if the participants had trouble carrying out normal activities such as their job, housework or hobbies due to the symptoms they are having over the last 12 months. A body map to indicate the 9 body parts was included to assist in the questionnaire; and (ii) Segment 2: In this segment, further in-depth questions were asked in regard to work-related musculoskeletal symptoms affecting the neck, shoulders and lower back over the past 12 months. The additional 15 questions encompass any previous injuries to each of the 3 highlighted body regions, any effect on functional capability at work or home, length of the problems and any assessment conducted by a health professional. For this study, the researcher used the validated Malay Version of SNMQ which was previously used by Tamrin et al. ${ }^{27}$ SNMQ has been used in various occupations including agricultural workers or plantation workers, commercial bus drivers, healthcare personnel, and administrative workers. ${ }^{28-31}$

\section{Assessment of Ergonomic Factors}

Both an initial and advanced Ergonomic Risk Assessment (ERA) were then conducted by the researcher who is trained in ERA in accordance with the Malaysian Guidelines on Ergonomic Risk Assessment at Workplace 2017. ${ }^{32}$ The ergonomic risk assessment involves a musculoskeletal assessment, followed by identification as well as further evaluation of the ergonomic hazard or risk factors recognised based on the observation and analysis of the completed tasks as stated in the Guidelines on Ergonomic Risk Assessment at Workplace 2017. ${ }^{32}$

Before the ERA was conducted, the landscape workers were interviewed by the researcher to gain a better understanding of their job tasks and demands. They were categorised into subgroups based on their job descriptions. The workers' movements and postures were then observed and analysed over several work cycles to identify the ergonomic risk factors and to determine if advanced ERA was needed. Selection of the postures to be evaluated was based on (i) the most difficult postures and work tasks; (ii) the posture sustained for the longest period of time; and (iii) the posture where the highest force loads occur. Risk factors identified initially included awkward posture, forceful exertion, and repetitive motion. Scores for initial assessment were given based on the task performed in which each risk factor was observed and analysed. Factors that had scores that met the minimum requirement for advanced assessment were then followed up with advanced ERA.

A rapid entire body assessment (REBA) tool, using a single page worksheet to evaluate the required or selected body posture, forceful exertions, types of movement of action, repetition, and coupling, was chosen for advanced ERA. $^{33,34}$ The REBA ergonomic tool uses a methodical process to evaluate both the upper and lower parts of the musculoskeletal system for biomechanical and MSD risks associated with the job task being evaluated.

The REBA tool consists of two sections, in which section $\mathrm{A}$ assesses the neck, trunk, and legs, while section $\mathrm{B}$ evaluates the arms and wrists. Scores are entered for each body region in both sections $\mathrm{A}$ and $\mathrm{B}$. The output of the REBA assessment tool is the final REBA score, which is a single score that characterises the level of MSD risk for the job task under evaluation. The scoring system is divided into four action levels, with indications of the need for change based on the risk level as displayed in Table $1 .^{34}$

Video recordings and photographs taken during assessment were further analysed by an Occupational Health Doctor who is trained in initial and advanced ERA to 
Table I REBA Score, Level of MSD Risk Descriptions and Actions Needed

\begin{tabular}{|l|l|}
\hline Score & Level of MSD Risk and Actions Needed \\
\hline 1 & Negligible risk; No action required \\
$2-3$ & Low Risk; Changes may be needed \\
$4-7$ & Medium Risk; Further investigation, change soon \\
$8-10$ & High Risk; Investigate and implement change \\
$11+$ & Very High Risk; Implement change \\
\hline
\end{tabular}

Note: Rapid entire body assessment: A literature review $2016 .{ }^{35}$

Abbreviations: REBA, rapid entire body assessment; MSD, musculoskeletal disorder.

confirm the findings of the researcher as well as to prevent any research bias. Written informed consents were obtained from the participants prior to study commencement.

\section{Statistical Analysis}

Initial data was collected using Microsoft Excel and no missing data identified. Data were then exported, analysed and results were generated using SPSS statistical package version 26.0. Descriptive statistics, which included frequency, percentage, median and interquartile range, were used to summarize and explain the independent variables (sociodemographic factors) and dependent variables (WRMSDs). Fisher's Exact Test was used to determine the association between the categorical independent and dependent variables since sample size was small and present of small cell numbers $(<5)$ in the analysis.

\section{Results}

\section{Personal Characteristics}

Majority of the respondents in this study consisted of male landscape workers (61.8\%), age group less than or equal to 44 years old $(56.4 \%)$, illiterate or low level of education (81.8\%), earning less than or equal to RM950 per month $(52.7 \%)$ and had 3 or less years of working experiences in the current job scope (50.9\%). Further details regarding personal characteristics of the landscape workers are described in Table 2. The workers worked for an average of 8 hours a day, from 7.30 am to $4.30 \mathrm{pm}$. They would start their work at 7.30 am before taking a short 15 -minute break in the morning (10.00 am to $10.15 \mathrm{am})$ and another 1-hour break for lunch $(12.00 \mathrm{pm}$ to $1.00 \mathrm{pm})$. Work

Table 2 Personal Characteristics of Landscape Workers $(\mathrm{N}=55)$

\begin{tabular}{|c|c|c|c|c|}
\hline \multirow[t]{2}{*}{ Personal Characteristics } & \multirow[t]{2}{*}{$\mathrm{n},(\%)$} & \multicolumn{2}{|c|}{ WRMSDs Past 12 Months } & \multirow[t]{2}{*}{ Median (IQR) } \\
\hline & & Yes, n (\%) & No, n (\%) & \\
\hline \multicolumn{5}{|l|}{ Gender } \\
\hline Male & $34(61.8)$ & $28(82.4)$ & $6(17.6)$ & \\
\hline Female & $21(28.2)$ & $19(90.5)$ & $2(9.5)$ & \\
\hline Age Group (years) & & & & $44(21)$ \\
\hline$\leq 44$ & $31(56.4)$ & $26(83.9)$ & $5(16.1)$ & \\
\hline$>44$ & $24(43.6)$ & $21(87.5)$ & $3(12.5)$ & \\
\hline \multicolumn{5}{|l|}{ Ethnicity } \\
\hline Bajau & $33(60.0)$ & $25(75.8)$ & $8(24.2)$ & \\
\hline Dusun & $10(18.2)$ & $10(100.0)$ & $0(0.0)$ & \\
\hline Others & $12(21.8)$ & $12(100.0)$ & $0(0.0)$ & \\
\hline \multicolumn{5}{|l|}{ Level of Education } \\
\hline None & $18(32.7)$ & $15(83.3)$ & $3(16.7)$ & \\
\hline Primary School & $27(49.1)$ & $24(88.9)$ & $3(I I . I)$ & \\
\hline Secondary School & $10(18.2)$ & $8(80.0)$ & $2(20.0)$ & \\
\hline Household Income & & & & $950(300)$ \\
\hline$\leq$ RM950 & $29(52.7)$ & $27(93.1)$ & $2(6.9)$ & \\
\hline > RM950 & $26(47.3)$ & $20(76.9)$ & $6(23.1)$ & \\
\hline \multicolumn{5}{|l|}{ Years of Working } \\
\hline$\leq 3$ years & $28(50.9)$ & $24(85.7)$ & $4(14.3)$ & \\
\hline$>3$ years & $27(49.1)$ & $23(85.2)$ & $4(14.8)$ & \\
\hline
\end{tabular}

Abbreviations: IQR, interquartile range; WRMSD, Work-related Musculoskeletal Disorders; IQR, interquartile range. 
would resume after the lunch break, and they finished work at $4.30 \mathrm{pm}$.

\section{Prevalence of Work-related Musculoskeletal Symptoms}

The overall prevalence of self-reported WRMSDs over a 12-months period, based on the SNMQ, was $85.5 \%$ (47 workers), while the remaining eight workers $(14.5 \%)$ did not complain of any symptoms. Female workers were noted to have a higher prevalence of self-reported WRMSDs (90.5\%) than their male counterparts (82.4\%). The highest prevalence of WRMSD symptoms according to body region over the past 12-months was shoulder region (65.5\%) followed by neck (23.6\%), wrist/hand (23.6\%) and lower back (20.0\%). On the other hand, while shoulder region remained the highest prevalence of WRMSD symptoms for the past seven days (34.5\%), the second highest was lower back (9.1\%) followed by knee region $(9.1 \%)$. Details of the WRMSDs symptoms among the landscape workers according to body region over past 12 months and 7 days is presented in Table 3. Forty-five percent or 25 of the landscape workers reported symptoms in more than one body region.

\section{REBA Risk Level Among the Landscape Workers}

Table 4 highlights the significant postures and movements which were scored according to the criteria or descriptions in the REBA tool. Table 5 presents the overall REBA scoring among the landscape workers according to their subgroups which were analysed based on their movements and postures at work. None of the workers was in the negligible or low-risk group. Thirty-nine workers (70.9\%), comprised of workers in group A and B, were in the medium-risk group, which warranted further investigations and urgent changes, while the remaining 16 workers or $29.1 \%$ were considered to be in the very high-risk group, which required immediate intervention.

\section{Association of Musculoskeletal Disorders and Its Risk Factors}

There were no significant association $(p<0.05)$ noted from the Fisher's Exact Test analysis of self-reported prevalence of musculoskeletal disorders and other risk factors which include REBA risk level. Details of the bivariate analysis conducted are illustrated in Table 6 .

\section{Discussion}

The overall prevalence of WRMSDs in the past 12 months among the landscape workers in a university setting was $85.5 \%$. It was noted to be lower compared to the study conducted among oil palm workers in Thailand which reported WRMSDs prevalence of $98.4 \%{ }^{35}$ Nevertheless, the overall prevalence in this study was still higher compared to previous studies involving other occupations. ${ }^{36-39}$ This was mainly contributed by the constant exposure to intensive manual tasks throughout their 8 hours of work per day, which usually involved repetitive actions, awkward postures, and sometimes heavy forceful exertion.

Awkward posture was the main ergonomic risk factor identified, and none of the working postures during assessment was appropriate. Seventy-one percent of the landscape workers were in the medium-risk group, warranting further investigations and urgent changes, while the

Table 3 Prevalence of Work-related Musculoskeletal Disorder Symptoms Among Landscape Workers According to Body Region Over Past 12 Months and Past 7 Days (N=55)

\begin{tabular}{|c|c|c|c|}
\hline Body Regions & $\begin{array}{l}\text { WRMSDs Symptoms* in the } \\
\text { Last } 12 \text { Months, } \mathbf{n}(\%)\end{array}$ & $\begin{array}{l}\text { Prevented from Doing Any Normal Work or } \\
\text { Activities in the Last } 12 \text { Months, } n(\%)\end{array}$ & $\begin{array}{l}\text { WRMSDs Symptoms* in } \\
\text { the Last } 7 \text { Days, } n \text { (\%) }\end{array}$ \\
\hline Neck & $13(23.6)$ & $5(9.1)$ & $3(5.5)$ \\
\hline Shoulder & $36(65.5)$ & $8(14.5)$ & $19(34.5)$ \\
\hline Elbow & $2(3.6)$ & $0(0.0)$ & I (I.8) \\
\hline Wrist/Hand & $13(23.6)$ & $3(5.5)$ & $4(7.3)$ \\
\hline Upper Back & $2(3.6)$ & $0(0.0)$ & $0(0.0)$ \\
\hline Lower Back & II (20.0) & I (I.8) & $7(12.7)$ \\
\hline Hip/Thigh & $2(3.6)$ & I (I.8) & I (I.8) \\
\hline Knee & $8(\mid 4.5)$ & I (I.8) & $5(9.1)$ \\
\hline Ankle/Feet & $7(12.7)$ & I (I.8) & $4(7.3)$ \\
\hline
\end{tabular}

Note: *WRMSDs symptoms were defined as having symptoms such as ache, pain, discomfort and numbness. 
Table 4 Postures and Movements of Landscape Workers According to Job Descriptions

\begin{tabular}{|c|c|}
\hline Categories of Workers with Job Descriptions & Postures and Movements \\
\hline $\begin{array}{l}\text { Group A } \\
\text { This group of landscape workers spent the whole day raking the dried leaves } \\
\text { and collecting them into large sacks around the areas assigned to them. They } \\
\text { worked continuously for } 2 \text { to } 3 \text { hours before taking short breaks. }\end{array}$ & $\begin{array}{l}\text { Raking the leaves } \\
\text { - Neck is moved } 10^{\circ} \text { to } 20^{\circ} \text { in flexion; twisted } \\
\text { - Trunk is moved } 20^{\circ} \text { to } 30^{\circ} \text { in flexion; twisted } \\
\text { - Upper arm is moved } 45^{\circ} \text { to } 90^{\circ} \text { in flexion; abducted } \\
\text { - Lower arm is moved } 0^{\circ} \text { to } 90^{\circ} \text { in flexion and across midline } \\
\text { - Wrist is in } 0^{\circ} \text { to } 15^{\circ} \text { flexion or extension and twisted in line }\end{array}$ \\
\hline \multirow[t]{3}{*}{$\begin{array}{l}\text { Group B } \\
\text { This group of landscape workers spent } 60 \text { to } 70 \% \text { of their daily working time } \\
\text { watering the plants and pulling the weeds all around UMS. Average working } \\
\text { hours about } 2 \text { to } 2.5 \text { hours continuously. Other task includes ploughing the } \\
\text { soil }\end{array}$} & $\begin{array}{l}\text { (i) Watering the plants } \\
\text { - Neck is moved } 10^{\circ} \text { to } 20^{\circ} \text { in flexion; } \\
\text { - Trunk is moved } 10^{\circ} \text { to } 20^{\circ} \text { in flexion } \\
\text { - Upper arm is moved } 20^{\circ} \text { to } 45^{\circ} \text { in flexion } \\
\text { - Wrist is in } 0^{\circ} \text { to } 15^{\circ} \text { flexion or extension and twisted in midline }\end{array}$ \\
\hline & $\begin{array}{l}\text { (ii) Pulling the weeds } \\
\text { - Neck is moved } 10^{\circ} \text { to } 20^{\circ} \text { in flexion; } \\
\text { - Trunk is moved } 20^{\circ} \text { to } 60^{\circ} \text { in flexion } \\
\text { - Upper arm is moved } 45^{\circ} \text { to } 90^{\circ} \text { in flexion } \\
\text { - Wrist is in } 0^{\circ} \text { to } 15^{\circ} \text { flexion or extension and twisted in midline } \\
\text { Squatting }\end{array}$ \\
\hline & $\begin{array}{l}\text { (iii) Ploughing the soil } \\
\text { - Neck is moved } 10^{\circ} \text { to } 30^{\circ} \text { in flexion; twisted } \\
\text { - Trunk is moved } 20^{\circ} \text { to } 30^{\circ} \text { in flexion; twisted } \\
\text { - Upper arm is moved } 45^{\circ} \text { to } 90^{\circ} \text { in flexion } \\
\text { - Lower arm is moved } 0^{\circ} \text { to } 90^{\circ} \text { in flexion and across midline } \\
\text { - Wrist is in } 0^{\circ} \text { to } 15^{\circ} \text { flexion or extension and twisted in midline }\end{array}$ \\
\hline \multirow[t]{2}{*}{$\begin{array}{l}\text { Group C } \\
\text { This group of workers spent } 60 \text { to } 70 \% \text { of their daily working time trimming } \\
\text { the hedges/overgrown branches or clearing the drain. They worked } \\
\text { continuously for } 2 \text { to } 3 \text { hours before taking short breaks in between. }\end{array}$} & $\begin{array}{l}\text { (i) Trimming the hedges } \\
\text { - Neck is moved } 10^{\circ} \text { to } 20^{\circ} \text { in flexion; twisted } \\
\text { - Trunk is moved }>60^{\circ} \text { in flexion; twisted/ side bending } \\
\text { - Upper arm is moved } 45^{\circ} \text { to } 90^{\circ} \text { in flexion; abducted } \\
\text { - Lower arm is moved }>90^{\circ} \text { in flexion } \\
\text { - Wrist is in }>15^{\circ} \text { flexion or extension and twisted in midline }\end{array}$ \\
\hline & $\begin{array}{l}\text { (ii) Clearing the drains } \\
\text { - Neck is moved } 10^{\circ} \text { to } 20^{\circ} \text { in flexion; twisted/side bending } \\
\text { - Trunk is moved }>60^{\circ} \text { in flexion; twisted/ side bending } \\
\text { - Upper arm is moved } 45^{\circ} \text { to } 90^{\circ} \text { in flexion; intermittent abduction } \\
\text { - Lower arm is moved } 0^{\circ} \text { to } 90^{\circ} \text { in flexion } \\
\text { - Wrist is in }>15^{\circ} \text { flexion or extension and twisted in midline }\end{array}$ \\
\hline
\end{tabular}

Table 5 REBA Score According to Subgroups Among Landscape Workers ( $N=55)$

\begin{tabular}{|l|c|c|c|}
\hline \multirow{2}{*}{ Categories of Workers } & \multicolumn{2}{|c|}{ Work-related Musculoskeletal Disorders } & \multirow{2}{*}{ REBA Score (Risk Level) } \\
\cline { 2 - 4 } & Yes, $\mathbf{n}(\%)$ & No, n (\%) & \\
\hline Group A & $28(87.5)$ & $4(12.5)$ & 7 (Medium) \\
Group B & $6(85.7)$ & $1(14.3)$ & $6-7$ (Medium) \\
Group C & $13(81.3)$ & $3(18.7)$ & (I) (Very High) \\
\hline Total & $47(85.5)$ & $8(14.5)$ & \\
\hline
\end{tabular}


Table 6 Work-related Musculoskeletal Disorders and Its Associated Risk Factors Amongst Landscape Workers (N=55)

\begin{tabular}{|c|c|c|c|}
\hline \multirow[t]{2}{*}{ Risk Factors } & \multicolumn{2}{|c|}{ WRMSDs Past 12 Months } & \multirow[t]{2}{*}{ p-value (Two-Sided) } \\
\hline & Yes, n (\%) & No, n (\%) & \\
\hline Gender & & & 0.696 \\
\hline Male & $28(82.4)$ & $6(17.6)$ & \\
\hline Female & $19(90.5)$ & $2(9.5)$ & \\
\hline Age Group (years) & & & 1.000 \\
\hline$\leq 44$ years & $26(83.9)$ & $5(16.1)$ & \\
\hline$>44$ years & $21(87.5)$ & $3(12.5)$ & \\
\hline Household Income & & & 0.131 \\
\hline$\leq$ RM950 & $27(93.1)$ & $2(6.9)$ & \\
\hline > RM950 & $20(76.9)$ & $6(23.1)$ & \\
\hline Education Level & & & 0.627 \\
\hline None or Primary One & $39(86.7)$ & $6(13.3)$ & \\
\hline Secondary & $8(80.0)$ & $2(20.0)$ & \\
\hline Years of Working & & & 1.000 \\
\hline$\leq 3$ years & $24(85.7)$ & $4(14.3)$ & \\
\hline$>3$ years & $23(85.2)$ & $4(14.8)$ & \\
\hline REBA Risk Score & & & 0.678 \\
\hline Medium Risk & $34(87.2)$ & $5(12.8)$ & \\
\hline Very High Risk & $13(8 \mid .3)$ & $3(18.7)$ & \\
\hline
\end{tabular}

Note: Fisher's Exact Test: significant if $p<0.05$.

remaining $29 \%$ were in the very high-risk group, requiring immediate intervention.

Even though there was no significant association, female workers reported a higher prevalence of WRMSDs (90.5\%) compared to their male counterparts. This finding supports those of previous studies, ${ }^{40-43}$ which reported a higher prevalence of WRMSDs among females compared to males in various working populations. Smith and Anderson, ${ }^{44}$ as well as Seifert and Messing ${ }^{45}$ stated that women have higher susceptibility to MSDs, mainly due to their anthropometric differences from men. On the other hand, Strazdins and Bammer indicated that females tend to be more sensitive to pain and have lower pain thresholds. $^{41}$

In addition, the self-reported prevalence of WRMSDs was noted to be higher among the older age group of $>44$ years $(87.5 \%)$ than in the younger age group of $\leq 44$ years (83.9\%) although no significant association was noted in bivariate analysis. This outcome supports the findings of previous studies, which indicated that the prevalence of MSDs increased with age. ${ }^{46-49}$ The older working population is more susceptible to musculoskeletal injuries, mainly due to the ongoing degenerative biological changes that are further aggravated by the constant imbalance between working capacity and the amount of workload expected from them. ${ }^{50}$

Majority of the landscape workers were paid daily wages, which meant that they would only be paid if they came to work. This may also influence their decision not to rehabilitate when they experienced mild WRMSDs symptoms due to financial constraints. Hence, even though there was no significant association, the prevalence of WRMSDs was noted to be higher among the lower household income group ( $\leq$ RM950; 93.1\%) compared to those in the higher household income group (>RM 950; 76.9\%). This finding was in line with the study conducted by Choi et al, ${ }^{51}$ who reported a higher prevalence of WRMSDs in lower income groups among Korean adults. Nevertheless, another study among garment workers in Bangladesh ${ }^{52}$ reported no significant association between the prevalence of WRMSDs and the income received by workers.

Awkward posture was the main ergonomic risk identified during the initial assessment of the landscape workers. REBA was chosen as the tool for advanced assessment. 
None of the workers was in the negligible risk group, which means none was in suitable postures while working. The self-reported discomfort, aches, and pain mostly involved the upper limbs, particularly the shoulders (65.5\%), neck (23.6\%), and wrist/hand (23.6\%), as well as the lower back $(20.0 \%)$ regions. These findings are in line with the findings in the Labour Force Survey 2019 which reported that $44 \%$ of the WRMSDs involved the upper limbs and neck, followed by the back $37 \%$ and $19 \%$ in the lower limbs. ${ }^{2}$ Nevertheless, two previous studies conducted among gardeners reported low back pain as the commonest WRMSDs followed by lower extremities and neck region. ${ }^{53,54}$

Awkward posture refers to conditions in which the body swerved considerably from its neutral position while carrying out work tasks. Workers were exposed to awkward postures, particularly when their limbs, joints, or back were extended in one part, while the other body parts were flexed, bent, or twisted. This caused unnecessary additional force on the joints and amplified the exertion of the tendons and muscles around the affected joints, as more strength was needed to complete the tasks. The risk was further exacerbated when their tasks were repetitive, and they needed to complete certain tasks within a given designated time. When forceful muscle exertion or contraction lasts for long periods of time, it reduces blood flow to the muscles, which leads to the accumulation of lactic acid that irritates the muscles and causes soreness or aches. Swollen and inflamed muscular tissues also compress the nerves, which further causes muscle weakness, numbness, or tingling sensation ("pins and needles"). Furthermore, when the tendons are repeatedly tensed, some of its fibres can tear, causing more inflammation and pain. Hence, persistent strenuous and repetitive chores, particularly in an awkward posture, combined with unexpected work stress and continuous cumulative strain, caused the majority of the landscape workers to experience WRMSDs symptoms.

The main strength of this research was that the framework of this study can be adapted as a template for compulsory yearly or regular screening of musculoskeletal symptoms in new or existing employees. This will reinforce the surveillance management for WRMSDs and assist in observing and predicting the progress of musculoskeletal symptoms experienced by workers in association with the ergonomic risk factors identified. In addition, it will also facilitate early recognition of unreported WRMSDs among landscape workers.
A few limitations were noted during the study. Even though $92 \%$ of the landscape workers in UMS participated in this study, the population size studied was still considered small and would not be representative of the actual population of landscape workers. Furthermore, since this was a crosssectional study, the information collected and the risk assessment conducted was based on a particular point of time. Hence, there was a constraint in outlining the actual exposure to the various ergonomic risk factors and its subsequent WRMSDs outcomes even though a few observations were conducted and analysed for each job categories at different points of time.

\section{Conclusion}

Early detection of ergonomic risk factors is indeed crucial considering a high (85.5\%) self-reported WRMSDs symptoms among the landscape workers. Besides, none of the workers was in suitable working postures which exposed them to medium or high risk of WRMSDs according to REBA. Therefore, comprehensive sustainable surveillance which includes control and prevention measures ought to be implemented. The recommendations include enhanced awareness campaigns and alterations to height adjustable working tools which may limit long-term exposure to awkward postures. Besides that, other suggestions would be improvement in administrative approaches by implementing frequent work rotations as well as additional short breaks in between work. These steps could assist in delaying or preventing the occurrence of WRMSDs, which have effects on both work efficiency and productivity as well as economic encumbrance to both employers and employees. In future studies, other ergonomic risk factors, such as repetitive movements and forceful workload, should be explored further in each job category.

\section{Abbreviations}

CDC, Centre for Disease Control and Prevention; DOSH, Department of Occupational Safety and Health; ERA, Ergonomic Risk Assessment; GBD, Global Burden and Disease; MSD, Musculoskeletal Disorders; REBA, Rapid Entire Body Assessment; SNMQ, Standardized Nordic Musculoskeletal Questionnaire; WRMSD, Work-related Musculoskeletal Disorder.

\section{Ethics Approval and Informed Consent}

Ethical approval from Ethical Committee of Faculty of Medicine and Health Sciences UMS was obtained to 
proceed with the study [Approval Code: JKEtika 1/20 (3)]. All the necessary information was explained to the respondents thoroughly which included the nature and purpose of the study, the methods and tools which were used, video recordings and photographs taken while they were at work, as well as the potential benefits of their involvement in this study. Consent forms were given to the respondents and were signed before the study was conducted. The respondents were assured and informed that all information and decisions resulting from this study will be kept strictly confidential in accordance with the law. The study was conducted in accordance with the Declaration of Helsinki.

\section{Consent for Publication}

Respondents were informed prior to study that images may be used for academic publication with their identity hidden as appropriately and informed consent was given before the study was conducted.

\section{Acknowledgments}

The authors are sincerely grateful to the Medical Ethics Committee and UMS for permitting us to conduct the research. We are also thankful to UMS for awarding us with the UMSGreat Grant, which was definitely a great financial support for the research. A sincere appreciation also to the Department of Development and Maintenance UMS and all the officers-in-charge of the cleaning services for their assistance in making all the necessary arrangements prior to the research. Besides that, the authors would also like to express their earnest appreciation to Professor Dr Shamsul Bahri Mohd Tamrin (Director, Centre of Industry Relations and Network, Universiti Putra Malaysia) for sharing and granting us the permission to use the validated Malay version of Standardised Nordic Musculoskeletal Questionnaire (SNMQ). Last but not least, we were appreciative to all the workers who agreed to participate and gave us their fullest co-operation throughout this research.

\section{Author Contributions}

All authors contributed to data analysis, drafting or revising the article, have agreed on the journal to which the article will be submitted, gave final approval of the version to be published, and agree to be accountable for all aspects of the work.

\section{Funding}

This study was supported by Universiti Malaysia Sabah under UMSGreat Grant (Project Code: GUG0472-1/2020).

\section{Disclosure}

The authors declare that they have no competing interests.

\section{References}

1. Cieza A, Causey K, Kamenov K, Hanson SW, Chatterji S, Vos T. Global estimates of the need for rehabilitation based on the Global Burden of Disease study 2019: a systematic analysis for the Global Burden of Disease Study 2019. Lancet. 2020;396(10267):2006-2017. doi:10.1016/S0140-6736(20)32340-0

2. Health and Safety Executive. Work related musculoskeletal disorders in Great Britain (WRMSDs), 2020. Health Saf Exec. 2020; November:1-10.

3. Lamprecht A, Padayachy K. The epidemiology of work-related musculoskeletal injuries among chiropractors in the eThekwini municipality. Chiropr Man Ther. 2019;27(1):1-13. doi:10.1186/s12998-0190238-y

4. Da Costa BR, Vieira ER. Risk factors for work-related musculoskeletal disorders: a systematic review of recent longitudinal studies. $\mathrm{Am}$ $J$ Ind Med. 2010;53(3):285-323.

5. Mirmohammadi S, Yazdani J, Etemadinejad S, Asgarinejad H. A cross-sectional study on work-related musculoskeletal disorders and associated risk factors among hospital health cares. Procedia Manuf. 2015;3(Ahfe):4528-4534. doi:10.1016/j.promfg.2015.07.468

6. Gillespie RM, Herbert R, Punnett L. Women and Health. 1st ed. Elsevier Inc.; 2013:613-628 p.

7. Murray CJ, Abraham J, Ali MK, et al. The state of US health, 1990-2010: burden of diseases, injuries, and risk factors. JAMA. 2013;310(6):591-606. doi:10.1001/jama.2013.13805

8. Centers for Disease Control and Prevention (CDC). Work-related musculoskeletal disorders \& ergonomics; 2020 [Upated February 20, 2020; cited September 18, 2020]. Available from: https://www. cdc.gov/workplacehealthpromotion/health-strategies/musculoskele tal-disorders/index.html. Accessed July 30, 2021.

9. Kumar S. Theories of occupational musculoskeletal injury causation. In: Biomechanics in Ergonomics. 2nd ed. CRC Press; 2007, p. 21-58.

10. Punnett L, Wegman DH. Work-related musculoskeletal disorders: the epidemiologic evidence and the debate. J Electromyogr Kinesiol. 2004;14(1):13-23. doi:10.1016/j.jelekin.2003.09.015

11. Sultan-Taïeb H, Parent-Lamarche A, Gaillard A, et al. Economic evaluations of ergonomic interventions preventing work-related musculoskeletal disorders: a systematic review of organizational-level interventions. BMC Public Health. 2017;17(1):935. doi:10.1186/ s12889-017-4935-y

12. Buckle PW, Devereux JJ. The nature of work-related neck and upper limb musculoskeletal disorders. Appl Ergon. 2002;33:207-217. doi:10.1016/S0003-6870(02)00014-5

13. Walsh IAP, Oishi J, Coury HJCG. Clinical and functional aspects of work-related musculoskeletal disorders among active workers. Rev Saude Publica. 2008;42(1):108-116. doi:10.1590/S0034-8910200800 0100014

14. International Ergonomics Association (IEA). Human factors/ergonomics; 2000. Available from https://iea.cc/what-is-ergonomics/. Accessed July 30, 2021.

15. Knibbs LD. Occupational hazards to the health of professional gardeners. Int J Environ Health Res. 2014;24(6):580-589. doi:10.1080/ 09603123.2014.883594 
16. Centres for Disease Control and Prevention (CDC). Landscaping safety and health; 2017. Available from: https://blogs.cdc.gov/nioshscience-blog/2017/03/20/landscaping/. Accessed July 30, 2021.

17. National Association of Landscape Professionals (NALP). Musculoskeletal injuries; 2019. Available from: https://www.landsca peprofessionals.org/LP/Safety/Musculoskeletal_Injuries.aspx. Accessed July 30, 2021.

18. Henry LJ, Jafarzadeh Esfehani A, Ramli A, Ishak I, Justine M, Mohan V. Patterns of work-related musculoskeletal disorders among workers in palm plantation occupation. Asia Pac J Public Health. 2015;27(2):NP1785-NP1792. doi:10.1177/1010539513475657

19. Sukadarin EH, Md Deros B, Ghani JA, Ismail AR, Mokhtar MM, Mohamad D. Investigation of ergonomics risk factors for musculoskeletal disorders among oil palm workers using Quick Exposure Check (QEC). Adv Eng Forum. 2013;10:103-109. doi:10.4028/ www.scientific.net/AEF.10.103

20. Abid A, Arif MA. Prevalence of musculoskeletal disorder of upper limb in gardeners of Pakistan horticulture authority. PakJ Phys Ther. 2021;03(04):17-21. doi:10.52229/pjpt.v3i4.898

21. Thetkathuek A, Meepradit P, Sa-ngiamsak T. A Cross-sectional Study of musculoskeletal symptoms and risk factors in cambodian fruit farm workers in Eastern Region, Thailand. Saf Health Work. 2018;9 (2):192-202. doi:10.1016/j.shaw.2017.06.009

22. Barneo-alcántara M, Díaz-pérez M, Gómez-galán M, Pérez-alonso J, Callejón-ferre ÁJ. Musculoskeletal risks of farmers in the olive grove (Jaén-Spain). Agriculture. 2020;10:1-36. doi:10.3390/agriculture10 110511

23. Sombatsawat E, Luangwilai T, Ong-artborirak P, Siriwong W. Musculoskeletal disorders among rice farmers in Phimai District, Nakhon Ratchasima Province, Thailand. J Health Res. 2019;33 (6):494-503. doi:10.1108/JHR-01-2019-0009

24. Department of Occupational, Safety and Health (DOSH). Occupational and Safety Health Act 1994; 1994. Available from: https://www.dosh.gov.my/index.php/legislation/acts-legislation/2302-occupational-safety-and-health-act-1994-act-514/file. Accessed July 30, 2021.

25. Kuorinka I, Jonsson B, Kilbom A, et al. Standardised Nordic questionnaires for the analysis of musculoskeletal symptoms. Appl Ergon. 1987;18(3):233-237. doi:10.1016/0003-6870(87)90010-X

26. Crawford JO. The Nordic musculoskeletal questionnaire. Occup Med. 2007;57(4):300-301. doi:10.1093/occmed/kqm036

27. Tamrin SB, Yokoyama K, Jalaludin J, et al. The association between risk factors and low back pain among commercial vehicle drivers in Peninsular Malaysia: a preliminary result. Ind Health. 2007;45 (2):268-278. doi:10.2486/indhealth.45.268

28. López-Aragón L, López-Liria R, Callejón-Ferre AJ, Gómez-Galán M. Applications of the standardized Nordic questionnaire: a review. Sustainability. 2017;9(9):1-42. doi:10.3390/su9091514

29. Yusoff HM, Zawawi RA, Deros BM. Prevalence of lower limb pain and its associated factors among healthcare workers. J Mech Eng Sci. 2017;11(3):2930-2940. doi:10.15282/jmes.11.3.2017.13.0264

30. Awang Lukman K, Jeffree MS, Rampal KG. Lower back pain and its association with whole-body vibration and manual materials handling among commercial drivers in Sabah. Int J Occup Saf Ergon. 2019;25 (1):8-16. doi:10.1080/10803548.2017.1388571

31. Nur Azma BA, Rusli BN, Oxley J, Quek K. Work related musculoskeletal disorders in female nursing personnel: prevalence and impact. Int J Collab Res Intern Med Public Health. 2016;8(3):23-44.

32. Department of Occupational, Safety and Health (DOSH). Guidelines on ergonomic risk assessment at workplace 2017; 2017. Available from: https://www.dosh.gov.my/index.php/competent-person-form/ occupational-health/regulation/guidelines/ergonomic/2621-01-guide lines-on-ergonomics-risk-assessment-at-workplace-2017?path=guide lines/ergonomic. Accessed July 30, 2021.

33. McAtamney L, Hignett S. Rapid entire body assessment. Handb Hum Factors Ergon Methods. 1st ed. CRC Press. 2004;31:8-1-8-11
34. Al Madani D, Dababneh A. Rapid entire body assessment: a literature review. Am J Eng App Sci. 2016;9(1):107-118. doi:10.3844/ ajeassp.2016.107.118

35. Tewtow S, Bhuanantanondh P, Mekhora K. Prevalence of workrelated musculoskeletal disorders among Thai oil palm workers in Khao Phanom District, Krabi Province, Thailand. Ind Eng Manag Syst. 2019;18(4):630-637. doi:10.7232/iems.2019.18.4.630

36. Clari M, Garzaro G, Di Maso M, et al. Upper limb work-related musculoskeletal disorders in operating room nurses: a multicenter cross-sectional study. Int J Environ Res Public Health. 2019;16 (16):2844. doi:10.3390/ijerph16162844

37. Hossain MD, Aftab A, Al Imam MH, et al. Prevalence of work related musculoskeletal disorders (WMSDs) and ergonomic risk assessment among readymade garment workers of Bangladesh: a cross sectional study. PLoS One. 2018;13(7):1-18. doi:10.1371/journal.pone. 0200122

38. Abas NH, Nazri MI, Affandi HM, et al. A survey on work-related musculoskeletal disorders among construction trades. Int J Integr Eng. 2018;10(4):131-139.

39. Stankevitz K, Schoenfisch A, de Silva V, Tharindra H, Stroo M, Ostbye T. Prevalence and risk factors of musculoskeletal disorders among Sri Lankan rubber tappers. Int J Occup Environ Health. 2016;22(2):91-98. doi:10.1080/10773525.2016.1168073

40. Roquelaure Y, Ha C, Leclerc A, et al. Epidemiologic surveillance of upper-extremity musculoskeletal disorders in the working population. Arthritis Care Res. 2006;55(5):765-778. doi:10.1002/art.22222

41. Strazdins L, Bammer G. Women, work and musculoskeletal health. Soc Sci Med. 2004;58(6):997-1005. doi:10.1016/S0277-9536(03) 00260-0

42. Nordander C, Ohlsson K, Åkesson I, et al. Risk of musculoskeletal disorders among females and males in repetitive/ constrained work. Ergonomics. 2009;52(10):1226-1239. doi:10.1080/001401309 03056071

43. Ekberg K, Karlsson M, Axelson O, Björkqvist B, Bjerre-Kiely B, Malm P. Cross-sectional study of risk factors for symptoms in the neck and shoulder area. Ergonomics. 1995;38(5):971-980. doi:10.1080/00140139508925163

44. Smith CK, Anderson NJ. Work-related injuries among commercial janitors in Washington State, comparisons by gender. J Safety Res. 2017;62:199-207. doi:10.1016/j.jsr.2017.06.016

45. Seifert AM, Messing K. Cleaning up after globalization: an ergonomic analysis of work activity of hotel cleaners. Antipode. 2006;38 (3):557-578. doi:10.1111/j.0066-4812.2006.00595.x

46. Walker-Bone K, Palmer KT, Reading I, Coggon D, Cooper C. Prevalence and impact of musculoskeletal disorders of the upper limb in the general population. Arthritis Care Res. 2004;51(4):642651. doi:10.1002/art.20535

47. English CJ, Maclaren WM, Court-Brown C, et al. Relations between upper limb soft tissue disorders and repetitive movements at work. Am J Ind Med. 1995;27(1):75-90. doi:10.1002/ajim.4700270108

48. Karwan MK, Ahmad Azuhairi A, Hayati KS. Prevalence of upper limb disorders and associated factors with psychosocial and awkward posture among Public University workers in Malaysia. IOSR J Dent Med Sci Ver VII. 2015;14(5):77-88.

49. Kumar R, Kumar S. Musculoskeletal risk factors in cleaning occupation-a literature review. Int $J$ Ind Ergon. 2008;38(2):158-170. doi:10.1016/j.ergon.2006.04.004

50. De Zwart BCH, Broersen JP, Frings-Dresen MH, van Dijk FJ. Repeated survey on changes in musculoskeletal complaints relative to age and work demands. Occup Environ Med. 1997;54(11):793799. doi:10.1136/oem.54.11.793

51. Choi K, Park JH, Cheong HK. Prevalence of musculoskeletal symptoms related with activities of daily living and contributing factors in Korean adults. J Prev Med Public Health. 2013;46(1):39-49. doi:10.3961/jpmph.2013.46.1.39 
52. Jahan N, Das M, Mondal R, et al. Prevalence of musculoskeletal disorders among the Bangladeshi Garments Workers. Sikk Manipal Univ Med J. 2015;2(1):102-103.

53. Nandy S, Gangopadhyay S, Meghnad S. Musculoskeletal disorders among the gardeners: a cross sectional study. Int J Appl Res. 2017;3 (5):440-443.
54. Rushikesh RM Dr, Smita CP Dr, Chandrakant BP Dr, Khushboo TC. Prevalence of musculoskeletal disorders in gardeners. Int J Pharma Bio Sci. 2020;10(4):117-120. doi:10.22376/ijpbs/lpr.2020.10.4.L117120

\section{Publish your work in this journal}

Risk Management and Healthcare Policy is an international, peerreviewed, open access journal focusing on all aspects of public health, policy, and preventative measures to promote good health and improve morbidity and mortality in the population. The journal welcomes submitted papers covering original research, basic science, clinical \& epidemiological studies, reviews and evaluations, guidelines, expert opinion and commentary, case reports and extended reports. The manuscript management system is completely online and includes a very quick and fair peer-review system, which is all easy to use. Visit http://www.dovepress.com/testimonials.php to read real quotes from published authors.

Submit your manuscript here: https://www.dovepress.com/risk-management-and-healthcare-policy-journal 